\title{
Potency of probiotic therapy for dental caries prevention
}

\author{
Indah Listiana Kriswandini \\ Department of Oral Biology \\ Faculty of Dentistry, Airlangga University
}

Surabaya - Indonesia

\begin{abstract}
Probiotic therapy is one of the therapies to prevent dental caries prospectively. Such therapy has been used in the medical area but not in dentistry. Probiotic therapy is important to be done since this therapy study ecosystem in oral cavity which has many commensal bacteria more detail. The probiotic material used to prevent dental caries is the microorganism which counter microorganism causing dental caries and its virulent product (acid lactic). Veillonella sp. use lactic acid as the end product of S. mutans which cause the dental caries. The principle of probiotic therapy is the comensalism symbiosis found in oral cavity ecosystem. Veillonella sp could be added to anticipate the lactic acid which cause enamel demineralization. Hopefully dentist will apply probiotic therapy, so there will be more study of Veillonella sp. as probiotic material for dental caries prevention. Further research on Veillonella sp in probiotic therapy and Immunology need to be done to achieve the balance of ecosystem.
\end{abstract}

Key words: probiotic therapy, dental caries, Veillonella sp, preventive dentistry

Correspondence: Indah Listiana Kriswandini, c/o: Departemen Biologi Oral, Fakultas Kedokteran Gigi Universitas Airlangga. Jln. Mayjend. Prof. Dr. Moestopo No. 47 Surabaya.

\section{INTRODUCTION}

Probiotic therapy has been used and improved medical treatment. Its function is to neutralize pathogenic flora which attack intestinal organ. Probiotic therapy is done by inserting normal flora which is needed to neutralize pathogenic bacteria. Those normal flora could achieve organ target in alive condition. Through this therapy it is hoped that the number of normal flora in the organ's ecosystem could be balanced and the product of pathogen bacteria could be neutralized. Probiotic flora for dental caries theraphy can be served as beverage, tooth paste or oral rinse.

The probiotic therapy could potentially be used in oral cavity since the oral ecosystem has normal flora and pathogen flora. The normal floras live as commensal bacteria by using product of other bacteria in the same ecosystem. The example of normal flora in oral cavity is Veillonella $s p$. which use lactic acid of end product of S. mutans as a metabolic energy. ${ }^{1}$ Schonfeld $^{2}$ also mentioned that lactic acid which produced by some microorganisms, such as Streptococcus and Actinomyces, could be used as the energy source of microorganism of Veillonella and Neisseria. The lactic acid could inhibit the growth of certain organism, like yeast. The objective of this paper is to review the potential use of probiotic acid from commensal bacteria and end product of $S$. mutans for dental caries prevention.

\section{Oral probiotic}

The dental caries disease is characterized by local damage of tooth enamel and dentin, due to bacterial fermentation of carbohydrate diet. ${ }^{1}$ The main bacteria that damage the enamel are Streptococcus mutans, which is virulent and has important role on caries process by lactic acid formation. Dental caries problem occurs either in developed country or developing country.

Actually S.mutans is normal oral flora, in certain condition such as the excessive sucrose diet, bad oral hygiene and abnormalities of tooth structure; S.mutans would colonize very fast and produce lactic acid as end product. This acid product could decalcify enamel structure and cause irreversible caries. ${ }^{3}$

Streptococcus mutans get the energy from glycolytic pathway which produces lactic acid. Many kinds of organic acids caused by dental plaque bacteria, but lactic acid are the most dominant product which causes enamel decalcification. Carbohydrate which metabolized by dental plaque bacteria produce lactic acid and other acid such as piruvic acid and formic acid, can cause oral $\mathrm{pH}$ decline until 5.5.

The characteristics of Veillonella are coccus shape, gram negative and anaerob condition is needed for its growth. Three species of Veillonella in oral cavity are Veillonella parvula, Veillonella atypica and Veillonella dispar. The population of those species in oral cavity is approximately $3 \%{ }^{4}$ Veillonella sp has the energy from the result of organic acid fermentation which are piruvic acid, lactic acid or malatic acid, fumarat and oxalo acetate. The end results of metabolism process are acetic acid, propionic acid, $\mathrm{CO}_{2}$ and hydrogen which have weaker acid and less cariogenic than lactic acid. The results of lactic acid metabolism by Veillonella are vitamin $\mathrm{K}$ and $\mathrm{H}_{2}$. Vitamin $\mathrm{K}$ is needed for cell metabolism of the "black pigmented" and $\mathrm{H}_{2}$ is used for 
cell metabolism of Wolinella. ${ }^{5}$ The bacteria growth needs additional energy such as lactic acid or piruvic acid on the base medium of PY extract which contained Vancomycin antibiotic.

Formerly Veillonella parvula known as Staphylococcus parvulus which means "small". Then it was found another strain, Veillonella alcalescens. These two species have high similarity of DNA. ${ }^{6,14}$ The form of Veillonella is usually in a pair, single or group chain. A pair chain which has flat surface found in buccal mucosa, tongue surface, saliva and dental plaque. ${ }^{6,7}$

Veillonella atypica almost like parvula, and it could be differentiated by using the protein profile and DNA test which taken from buccal mucosa. On the other hand, Veillonella dispar in biochemistry test could break hydrogen peroxide and its growth needs putrechine. ${ }^{8,13}$ Normal floras in oral cavity have a lot of variety. Oral flora could help to balance the oral ecosystem. In oral ecosystem, there are bacteria which have commensally life by using other bacteria product. ${ }^{1}$

The bacteria which produced lactic acid, such as Streptococcus mutans and Lactobacillus, have the energy from glycolytic pathway. There are a lot of organic acid which are made by the dental plaque bacteria, but lactic acid is the most dominant product which cause enamel decalcification. The carbohydrate is metabolized by plaque bacteria became lactic acid and other acid (piruvic acid and formic acid). Lactic acid will be used by Veillonella $s p$. for reducing acetic acid and propionic acid. The acetic acid reduction is done through metil-malonil co-A carboxil transferase. With complex-biotin carbon dioxide, lactic acid is changed into oxalo acetic and reducted to malat, fumarat and succinate. Succinate is through to electron transport fosforilation and changed from co-A transferase (succinic co-A, propionic co-A transferase) into co-A derivat, then succinate will be activated. The intermediate product is divided by carbondioxide, so propionil co-A formed and propionic released from propionil-coA, while co-A transferase moved co-A to succinic. In the propionic formation, the two groups $\left(\mathrm{CO}_{2}\right.$ and co-A) are coming from the advanced product. It is moved into introduction phase without releasing that group. This process included three co-factors which are biotin, co-A and B12 coenzym. ${ }^{9}$

Probiotic is a group of certain microorganism when it is inserted in digestive tract; it gives good effect to prevent and gives specific therapy for pathological condition. This group of microorganism has biological effect such as colonization resistance. It gives enzyme which needed by digestive tract. ${ }^{10}$ The use of probiotic can modulate immune system contain commensally microorganism to inhibit the progress of pathogenic microorganism in its ecosystem. The inhibition process could be done by bacterial antagonism, bacterial interference barrier effect, colonization resistance and competitive exclusion. ${ }^{11,12}$

\section{DISCUSSION}

From the literature review revealing an idea to make an alternative plan for caries prevention by using probiotic therapy, since the oral cavity had specific ecosystem. The oral ecosystem has normal flora and pathogen flora which commensally live. It could use to balance the oral ecosystem. As we know $S$. mutans are the normal flora in oral cavity, and if its number is more than normal they would disturb the oral ecosystem and decalcified tooth enamel. ${ }^{1}$ Veillonella $s p$ is also oral normal flora. They live by using lactic acid. After metabolism process, they change from lactic acid to weaker acid: acetic acid, formic acid and propionic acid which is not cariogenic. ${ }^{5}$ Through commensally symbiosis Veillonella could reduce the potency of lactic acid causing enamel demineralization. ${ }^{1}$

The number of Veillonella sp in oral cavity is only $3 \%$. If the product of lactic acid produced by $S$. mutans is too much, the Veillonella sp could not use the excessive acid. ${ }^{4}$ Base on this concept the writer suggest that Veillonella $s p$. can be use as probiotic material for prevent dental caries. The probiotic therapy use Veillonella $s p$ because they could inhibit pathogenic agent through competition with nutrient. ${ }^{10,11}$ This probiotic theraphy has harmless effect because the bacteria use for therapy is normal flora of oral ecosystem.

Veillonella sp. gives more advantage as probiotic material than Lactobacillus sp. because it is normal oral flora and do not produce lactic acid. Veillonella $s p$ act as lactic acid user which assessed as enamel demineralization. Nevertheless, much research on Veillonella $s p$ is needed for proper probiotic material to prevent dental caries; e.g. antibiotic susceptibility test. The antibiotic test is intended to determine Veillonella sp survival on the patient which on antibiotic therapy. Lysozyme tolerance test is purposed to examine the survival of Veilonella $s p$. with lysozyme existence in oral cavity. ${ }^{15}$ Hopefully there will be more study on Veillonella $s p$ which used as probiotic material for dental caries prevention. Further research on number of Veillonella sp needed for probiotic therapy and immunological study should be done to achieve balance oral ecosystem.

\section{REFERENCES}

1. Marsh P, Martin MV. Acquisition, adherence, distribution and metabolism of the oral microflora. In oral microbiology. Great Britain: MPG Books Ltd; 2000. p. 34-57.

2. Schonfeld SE. Oral microbiology ecology. Contemporary oral microbiology and immunology. Chapter 16. In: Slots J, Taubman MA, editors. St. Louis, Missouri: Mosby Year Book; 1992. p. 267-74.

3. Lehner T. Immunology of oral diseases. $3^{\text {rd }}$ ed. London: Blackwell Scientific Publication; 1992. p. 70-1.

4. Nisengard RJ, Newman MG. Oral microbiology and immunology. $2^{\text {nd }}$ ed. Philadelphia : WB Saunders Co; 1994. p. 145-46. 
5. Harold. Oral microbial ecology and the role of salivary immunoglobulin A. Am Soc for Microbiology 1998; 62(1): 71-99.

6. Taubman MA. Immunological aspects of dental caries. Chapter 29. In: Slots J, Taubman MA, editors. Contemporary oral microbiology and immunology. St. Louis, Missouri : Mosby Year Book; 1992. p. 533-41.

7. Samaranayake L. Bacterial phisiology and genetics in essential microbiology for dentistry. $3^{\text {rd }}$ ed. Toronto: Harcourt Publisher Limited. Churchill Livingstone Elsevier; 2006.

8. Tanner A, Lai CH, Maiden M. Characteristics of oral Gram-negative species. Chapter 19. In: Slots J, Taubman MA, editors. Contemporary oral microbiology and immunology. St. Louis, Missouri : Mosby Year Book; 1992. p. 299-341.

9. Schlegel HG. Mikrobiologi umum. $6^{\text {th }}$ ed. Yogyakarta: Gadjah Mada University Press; 1994. p. 324-6.

10. Chow J. Probiotics and prebiotics: A brief overview. J Ren Nutr 2002 April; 12(2): 76-86.
11. Kailasapathy K, Chin J. Survival and therapeutic potential of probiotic organisms with reference to Lactobacillus acidophilus and Bifidobacterium spp. Immunol Cell Biol 2000 Feb; 78(1): 80-8.

12. Young RJ, Huffman S. Probiotic use in children. J Pediatr Health Care 2003 Nov-Dec; 17(6): 277-83.

13. Maiden MFJ, Lai CH, Tanner A. Characteristics of oral Gram-positive Bacteria. Chapter 20. In: Slots J, Taubman MA, editors. Contemporary oral microbiology and immunology. St. Louis, Missouri: Mosby Year Book; 1992. p. 342-72.

14. Rosen S. Dental caries. Chapter 33. Essential dental microbiology. In: Willet NP, White RR, Rosen S, editors. New Jersey: Prentice Hall, Englewood Cliffs, Printed in The Republic of Singapore; 1991. p. 341-56.

15. Koll P, Mandar R, Marcotte H, Lelbur E, Mikelsaar M, Hammarstrom L. Characterization of oral Lactobacilli as potential probiotic for oral health. Oral Microbiology and Immunology 2008; 23: 139-47. 